\title{
Analisis Perkiraan Biaya Ekonomi Deforestasi di Kalimantan Barat
}

\author{
Akhmad Yani* \\ Fakultas Ekonomi dan Bisnis, Universitas Tanjungpura, Indonesia
}

\begin{abstract}
Almost all forest areas in the districts / cities in West Kalimantan experience reduced area. Reducing the area of forest area or deforestation can, of course, have a detrimental impact on the environment which in turn can disrupt the sustainability of development itself. Deforestation has ecological, economic and social impacts. The higher the rate of deforestation, it will cause the potential impact will also increase. West Kalimantan experienced a fairly high level of deforestation. This gives an indication that the impact caused by deforestation in West Kalimantan has a relatively high potential. In other words, deforestation causes losses including economic losses. Related to this, the research question is how much economic value is the loss caused by deforestation in West Kalimantan? This research has 2 (two) objectives: first, calculating the economic costs of deforestation in West Kalimantan during the period 2009-2015, and second, analyzing the effect of the economic costs of deforestation on West Kalimantan's GDP during the period 2009-2015. Based on the data base for the period 2009 to 2015 and using the benefit transfer technique, this research has found that the highest economic losses occur in the secondary production forest and the lowest in the conservation forest area. Furthermore, during the period 2009 to 2015, this study has found that the highest economic loss value occurred in 2013 and the lowest occurred in 2011. Overall, the value of economic losses in the form of a combination of depletion and degradation provides a less significant reduction on the value of the forestry sub-sector GRDP in West Kalimantan.
\end{abstract}

JEL : Q51, Q56, R11

Keywords: deforestasi, deplesi, degradasi, nilai kerugian ekonomi deforestasi, Produk Domestik Regional Hijau (PDRH)

\section{PENDAHULUAN}

Indonesia dikenal memiliki hutan yang sangat luas di dunia setelah Brazillia. Namun selama lebih kurang 50 tahun hutan alam di Indonesia telah mengalami penyusutan secara drastis. Pada periode 1990 hingga 2001 laju deforestasi (penebangan hutan) di Indonesia mencapai 2 (dua) juta hektare per tahun, dan angka ini meningkat dua kali lipat dibanding 1980an (Forest Watch Indonesia, 2011). Kondisi tersebut sebagai akibat terjadinya eksploitasi hutan yang tidak memperhatikan aspek kelestarian hutan, sehingga menimbulkan kerusakan lingkungan, kepunahan jenis flora dan fauna, konflik sosial, hilangnya pendapatan pemerintah

\footnotetext{
* E-mail : akhyandinson@gmail.com

Received : 12-10-2018, Accepted : 06-11-2018, Published : 29-04-2019

P-ISSN : 2087 - 9954, E-ISSN : 2550 - 0066. DOI : http://dx.doi.org/10.26418/jebik. v8vi1.29108
} 
serta kegagalan mempertahankan sumber daya hutan untuk generasi mendatang. Pada gilirannya fungsi ekosistem hutan yang mendukung kehidupan manusia terabaikan, beragam kehidupan flora dan fauna yang membentuk mata rantai kehidupan yang bermanfaat bagi manusia menjadi rusak dan hilang. Ini terjadi karena berbagai faktor dengan penyebab utamanya antara lain penebangan liar, perambahan hutan dan kepentingan pembangunan non kehutanan lainnya. Oleh karena itu dalam 50 tahun terakhir tutupan hutan di Indonesia telah berkurang dari 162 juta hektare menjadi 98 juta hectare (Forest Watch Indonesia, 2011). Sementara itu (Forest Watch Indonesia dan Global Forest Watch, 2011) memperkirakan telah terjadi pengurangan penutupan hutan di Indonesia dari 162.3 juta ha di tahun 1950 menjadi sekitar 105 juta ha di tahun 2000 . Bahkan Departemen Kehutanan mengatakan bahwa laju kerusakan hutan mencapai 3,4 juta hektar per tahun yang diakibatkan oleh berbagai sebab(Adriana, 2004:1) . Diantara berbagai penyebab deforestasi di Indonesia, diperkirakan sekitar 2,5 juta ha akibat terjadinya penebangan hutan secara illegal.

Fenomena deforestasi terjadi juga di Kalimantam Barat yang merupakan salah satu provinsi dengan hutan terluas ke empat di Indonesia setelah Provinsi Papua, Kalimantan Tengah dan Kalimantan Timur. Berdasarkan SK Kementerian Kehutanan No.259/KPTS-II/2000, Kalimantan Barat memiliki hutan seluas 9.101 .760 ha. Selain itu, hutan yang berada di wilayah Kalimantan termasuk di Kalimantan Barat adalah kawasan HOB (Heart of Borneo), karena merupakan kawasan hutan yang memiliki keragaman spesies yang relative banyak. Namun pada sisi lain angka laju deforestasi di Kalimantan Barat rata-rata pertahun cukup signifikan yang mencapai 116.172,77 ha (Analisis Data Spasial Penafsiran Citra Lansat 2006 dan 2011, dalam REDD+ KALBAR, (2013). Dengan angka laju deforestasi yang cukup massive ini tentu saja sangat memberikan pengaruh terhadap fungsi hutan secara ekologis, bahkan juga memberikan dampak ekonomi dan social dalam jangka panjang bagi masyarakat. Deforesitasi yang dipahami sebagai berkurangnya tegakan dan tutupan hutan selain menimbulkan pengaruh terjadinya deplesi atau pengurangan luasan hutan, juga menyebabkan terjadinya penurunan atau degradasi fungsi-fungsi hutan sebagai sistem yang mendukung kehidupan bagi keberlanjutan dan kelangsungan hidup terutama masyarakat di Kalimantan Barat.

Dengan kata lain, deforestasi menimbulkan kerugian termasuk kerugian secara ekonomi. Terkait dengan hal ini, perlu adanya suatu pendekatan yang digunakan untuk menghitung nilai ekonomi kerugian yang ditimbulkan oleh terjadinya deforestasi di Kalimantan Barat. Dalam konteks ini penelitian ini mencoba menghitung perkiraan nilai biaya kerugian ekonomi akibat deforestasi selama periode tahun 2009 s/d 2015.

\section{KAJIAN LITERATUR}

\subsection{Paradigma Pembangunan Berkelanjutan dan Berwawasan Lingkungan}

Bila menelusuri dari awal perkembangan teori ekonomi hingga menjelang akhir tahun 80an, sebagian besar para ahli ekonomi tidak memperhatikan masalah lingkungan sebagai variable yang terkait dengan perekonomian terutama pertumbuhan ekonomi. Para ahli ekonomi terdahulu masih menganggap masalah lingkungan yang menyertai kegiatan perekonomian akan dapat diselesaikan dengan mekanisme sistem perekonomian yang berlaku (Arrow et al., 1995). Bhagwati, (1993) bahkan berpendapat bahwa pembangunan atau pertumbuhan ekonomi merupakan pra kondisi untuk perbaikan lingkungan. Hal ini diperkuat oleh Beckermen, (1992) 
yang mengemukakan bahwa korelasi yang kuat antara pendapatan dan ukuran perlindungan lingkungan memperlihatkan adanya hubungan yang positif antara kenaikan pendapatan dan kualitas lingkungan yang semakin baik. Selain itu Panayotou, (1993:14) menegaskan pula bahwa di negara-negara berkembang pertumbuhan ekonomi akan mendorong perbaikan lingkungan. Pada sisi lain, beberapa ahli memiliki pendapat yang berbeda dengan para ahli sebelumnya seperti yang disampaikan oleh Georgescu-Roegen, (1977) yang menyatakan bahwa pertumbuhan ekonomi tidak selaras dengan lingkungan berkelanjutan. Pendapat yang sama dikemukakan oleh Daly, (1977) yang menegaskan bahwa pertumbuhan ekonomi akan mendorong perekonomian dunia menuju batasnya atau daya dukung lingkungan yang semakin terbatas.

Namun perdebatan tentang teori pembangunan ekonomi pada akhirnya menuju kepada suatu konsep pembangunan yang disebut dengan pembangunan berkelanjutan (sustainable development). Meier \& Y, (2001) membuat alur perubahan pemikiran pembangunan yang semula bertumpu pada pertumbuhan berubah bertumpu pada keberlanjutan, dengan diagram sebagai berikut:

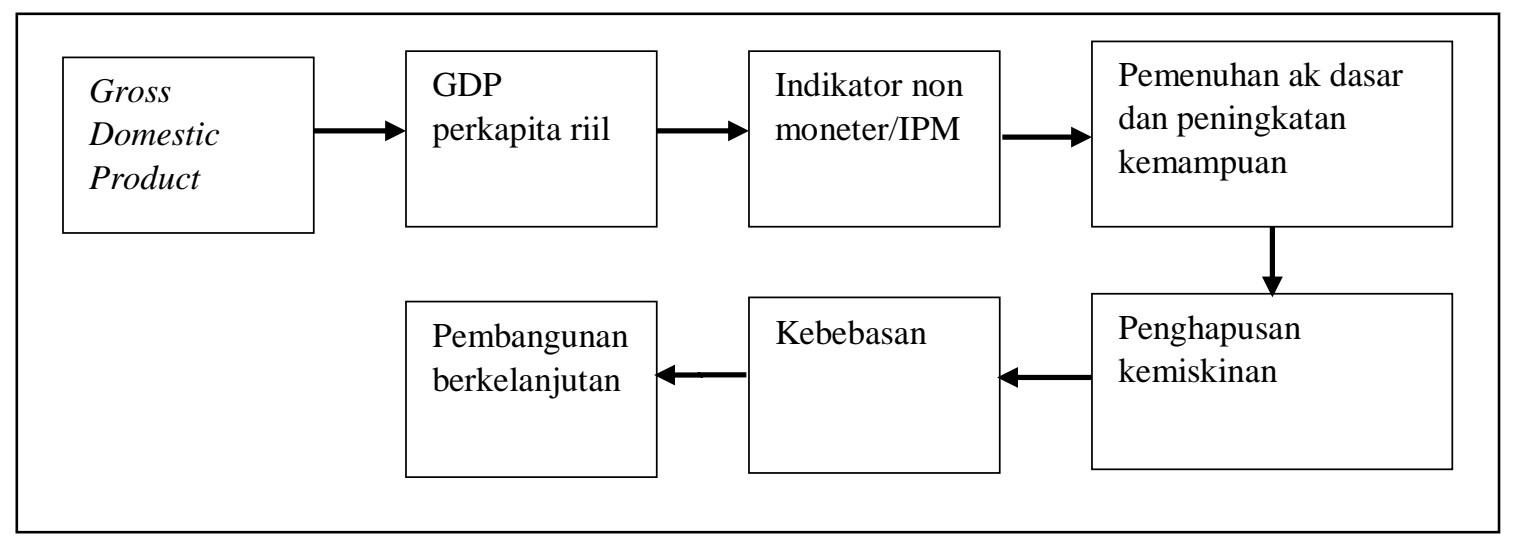

\section{Diagram 1. Alur Perubahan Pemikiran Pembangunan}

Sumber: Meier \& Y, (2001)

Sebagaimana konsep pembangunan yang berlandaskan pada pertumbuhan ekonomi, maka upaya untuk meningkatkan pertumbuhan ekonomi yang tinggi, membutuhkan eksploitasi sumberdaya alam yang massive. Namun pada tahap ini muncul pertanyaan, apakah sumberdaya alam yang ada cukup mampu tetap tersedia memenuhi kebutuhan dalam rangka mencapai pertumbuhan ekonomi yang tinggi sampai menuju tahap pembangunan berkelanjutan? Pertanyaan lain yang tidak kalah pentingnya adalah apakah upaya untuk menuju tahap pembangunan berkelanjutan harus dimulai dari tahapan pertumbuhan ekonomi yang tinggi? Sebagian ahli ekonomi berpendapat bahwa pembangunan ekonomi yang berpijak pada pertumbuhan ekonomi yang tinggi, pada akhirnya tidak akan mencapai tahap pembangunan berkelanjutan, jika pertumbuhan ekonomi tersebut sangat ditopang oleh eksploitasi sumberdaya alam yang massive.

\subsection{Dampak Pembangunan Ekonomi Terhadap Lingkungan}

Paradigma pertumbuhan ekonomi yang selama ini menjadi strategi pembangunan masih dipercaya mampu untuk meningkatkan kesejahteraan masyarakat. Sehingga dengan paradigma ini, semakin tinggi tingkat pertumbuhan ekonomi, maka semakin tinggi pula kualitas 
hidup masyarakat atau kesejahteraan masyarakat. Namun dibalik tingginya tingkat pertumbuhan ekonomi, penggunaan atau eksploitasi sumberdaya alam juga semakin tinggi. Hal ini tentu saja memberikan suatu indikasi, jika sumberdaya alam yang dieksploitasi semakin tinggi, maka degradasi lingkungan akan semakin cepat. Sehingga hal ini memberikan kesan bahwa terjadinya trade off antara pembangunan ekonomi dengan lingkungan. Dengan kata lain, upaya untuk meningkat kesejahteraan masyarakat melalui pembangunan ekonomi harus mengorbankan kualitas lingkungan yang semakin buruk. Sebaliknya upaya untuk mempertahankan kualitas lingkungan yang baik harus menunda upaya untuk mencapai tingkat kesejahteraan masyarakat yang tinggi. Pada dasarnya, tidak selamanya terjadi trade off antara pembangunan ekonomi dan kualitas lingkungan. Beberapa ahli ekonomi telah melakukan penelitian salah satunya adalah ) Barbier, Burgess, \& Folke, (1994); Stern et al., (1996) dan Ekins, (1997), yang mencoba mengamati hipotesis Kuznet dengan EKC (Environmental Kuznets Curve) yang melihat hubungan antara tingkat pendapatan perkapita dengan tingkat pencemaran. Kuznets mengemukakan bahwa pada tingkat pendapat yang rendah dan makin meningkat, maka tingkat polusi akan meningkat seiring dengan naiknya tingkat pendapatan perkapita. Namun ketika pendapatan perkapita mencapai tingkat tertentu, dan terus mengalami peningkatan, maka tingkat polusi mengalami penurunan. Hipotesis Kuznets ini memberikan makna bahwa dalam jangka pendek, kenaikan pendapatan perkapita menyebabkan peningkatan polusi, namun dalam jangka panjang kenaikan pendapatan perkapita justru diiringi dengan makin menurunnya tingkat polusi. Secara implisit dapat dikatakan bahwa dalam jangka pendek akan terjadi trade off antara pembangunan ekonomi dengan lingkungan, namun dalam jangka Panjang terjadi harmonisasi dan sinergi antara pembangunan ekonomi dengan lingkungan. Berikut ini kurva EKC yang menampilkan hubungan antara tingkat pendapatan perkapita dengan tingkat pencemaran/polusi.

\section{Kurva 1. Hubungan Antara Tingkat Pendapatan Perkapita dan Polusi}

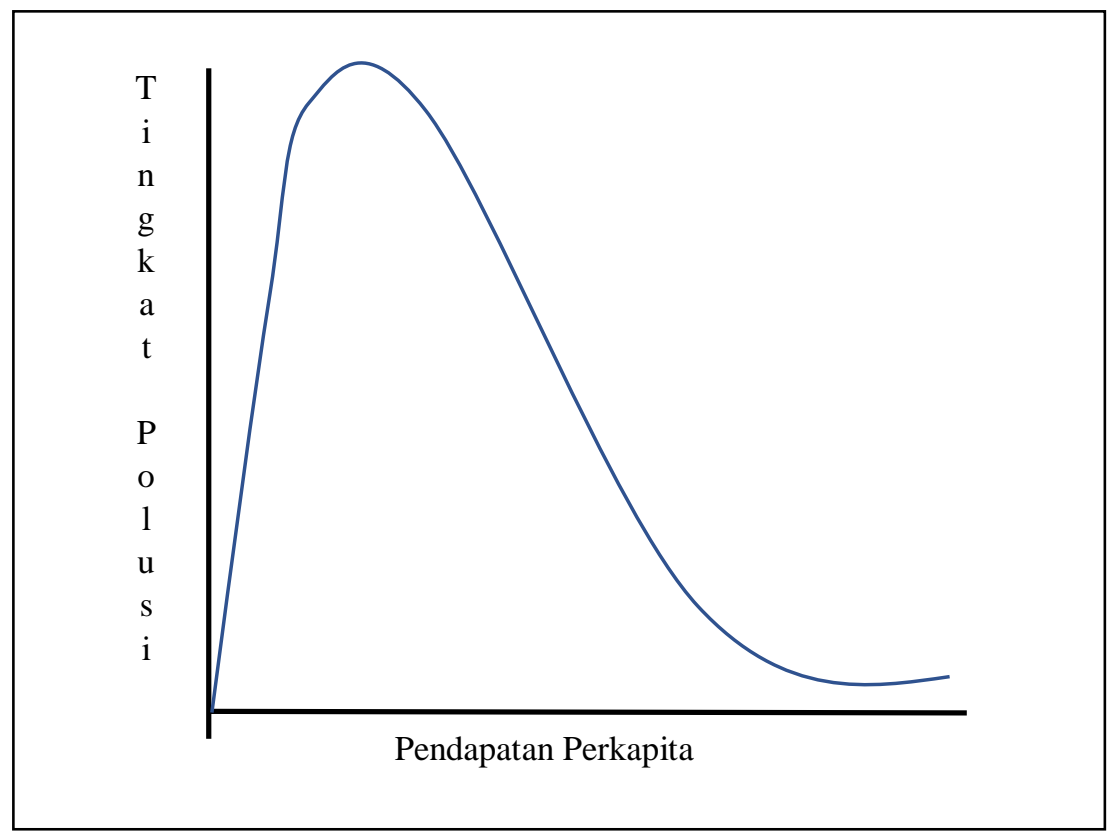

Sumber: Panayotou, (1993) dalam Stagl, (1999) 


\subsection{Ekonomi Hijau}

Konsep Ekonomi Hijau pertama kali diusulkan oleh United Nation Environment Program (UNEP) yaitu Badan Lingkungan Hidup Dunia PBB pada tahun 2010, dengan suatu konsep pembangunan bersama untuk perbaikan kondisi lingkungan hidup. Ekonomi Hijau didefinisikan sebagai suatu perekonomian yang berhasil meningkatkan kesejahteraam manusia secara merata dan signifikan dengan memperkecil resiko lingkungan dan kelangkaan ekologi (ecological scarcities). Ekonomi Hijau dicirikan oleh peningkatan investasi di sektor ekonomi yang dibangun atas dasar modal alami tetapi sekaligus berhasil memperkuat modal alami (natural capital) itu sendiri (Suparmoko \& Ratnaningsih, 2011). Ekonomi Hijau (Green Economy) memisahkan hubungan antara pertumbuhan ekonomi dengan pemanfaatan sumber daya alam yang berlebihan dan kerusakan lingkungan melalui pengembangan produk-produk baru, proses produksi, jasa dan cara hidup. Pada dasarnya ekonomi hijau mendorong terjadinya produk rendah karbon (termasuk proses dan delivery nya), namun saat ini ekonomi hijau lebih banyak mencakup perubahan penggunaan air, hutan, gaya hidup, dan keanekaragaman hayati, serta strategi penurunan emisi termasuk di dalamnya strategi mitigasi dan adaptasi terhadap perubahan iklim (Hernowo, 2011). Dalam konteks konsep ekonomi hijau, berbagai kebijakan, program dan kegiatan yang menuju kepada peningkatan / pertumbuhan ekonomi, menginternalisasi / memasukkan pertimbangan aspek lingkungan, menciptakan lapangan kerja yang layak, dan pengentasan kemiskinan merupakan wujud nyata penerapan elemen penting ekonomi hijau. Namun tentu saja program dan kegiatan atau kebijakan yang dilakukan untuk percepatan spirit ekonomi hijau dipastikan selalu menimbulkan biaya dan manfaat sebagai akibat kegiatan tersebut. Oleh karena itu dasar untuk menyatakan bahwa suatu kegiatan atau kebijakan itu layak atau tidak layak diperlukan suatu indikasi yang menunjukkan suatu nilai atau rasio. Untuk itu diperlukan suatu penilaian atau valuasi ekonomi terhadap dampak suatu kegiatan atau kebijakan terhadap lingkungan. Tanpa pemberian nilai dalam mata uang Dollar atau rupiah akan sulit bagi kita untuk menyatakan bahwa kegiatan itu layak adanya (Suparmoko, 2006).

\subsection{PDRB Konvensional}

Produk Domestik Regional Bruto (PDRB) adalah catatan tentang jumlah nilai rupiah dari barang dan jasa akhir yang dihasilkan oleh suatu perekonomian daerah (Provinsi/Kabupaten/Kota) untuk waktu satu tahun lamanya. Nilai PDRB suatu daerah tersebut sebenarnya sama dengan nilai tambah yang diciptakan oleh semua sektor kegiatan ekonomi (lapangan usaha) dalam wilayah atau daerah yang sama. PDRB sangat bermanfaat bagi perencanaan dan penilaian hasil-hasil pembangunan, oleh karena itu menjadi hal sangat penting bagi setiap provinsi, kabupaten dan kota di seluruh Indonesia menyusun PDRB dan menerbitkannya setiap tahun. Perhitungan PDRB yang selama ini dilakukan sebenarnya baru menghitung nilai total barang dan jasa akhir (final product) yang dihasilkan selama satu tahun dan dinyatakan dalam nilai rupiah. Nilai yang dihasilkan diyakini memberikan gambaran tentang pertumbuhan ekonomi yang dialami oleh suatu daerah, baik secara total maupun secara sektoral, sehingga dianggap dapat mencerminkan kesejahteraan daerah yang bersangkutan. Namun sesungguhnya tidaklah demikian, karena nilai sumber daya alam yang hilang (di eksploitasi) dan kerusakan (degradasi) lingkungan belum diperhitungkan atau dikurangkan sebagai nilai kehilangan dan kerusakan yang seharusnya dibayar, sehingga nilai-nilai yang tercantum dalam PDRB yang konvensional itu belum menunjukkan nilai kesejahteraan masyarakat yang sesungguhnya. Agar PDRB dapat mencerminkan nilai kesejahteraan yang sesungguhnya dari 
hasil kegiatan perekonomian suatu daerah, maka perlu dilakukan perhitungan PDRB yang disesuaikan (adjusted PDRB) atau lebih dikenal dengan PDRB Hijau. Perhitungan PDRB hijau ini dilakukan dengan memasukkan nilai sumber daya alam yang digunakan sebagai masukan (inputs) maupun nilai kerusakan (degradasi) lingkungan yang ditimbulkan sebagai akibat dilakukannya suatu kegiatan dalam perekonomian.

\subsection{PDRB Hijau}

Pada tingkat nasional, pertumbuhan ekonomi diukur dari pertambahan PDB. Apabila PDB meningkat, maka dapat diartikan bahwa terjadi pertumbuhan ekonomi. Upaya untuk meningkatkan PDB tanpa memperhatikan masalah lingkungan sering disebut dengan PDB coklat. Di sebagian besar negara-negara berkembang, pembangunan ekonomi masih sering diukur dari PDB coklat ini. Dalam konteks ini, jika tujuan pembangunan ekonomi adalah peningkatan kesejahteraan, maka perlu dipertanyakan apakah peningkatan kesejahteraan dapat dicapai dengan peningkatan PDB coklat saja. Jika terjadi peningkatan PDB coklat, berarti kapasistas produksi nasional secara aggregate meningkat. Masalah muncul ketika peningkatan kapasitas produksi nasional yang didorong peningkatan PDB coklat menimbulkan masalah lingkungan, yang pada gilirannya menyebabkan terjadinya degradasi kualitas lingkungan. PDB hijau adalah pengembangan dari PDB coklat, merupakan koreksi dari konsep PDB coklat yang tidak mengakomodasi kegagalan pasar. Keberadaan PDB hijau setidaknya menjadi media untuk mengurangi tekanan terhadap lingkungan. Karakteristik PDB hijau yang mengakomodasi degradasi lingkungan dan deplesi sumberdaya alam akan mengoreksi kelemahan-kelemahan dari PDB coklat.

Secara teoritis, penghitungan PDRB Hijau sangat sederhana yang dinyatakan ke dalam rumus : PDRB Hijau = PDRB Coklat - deplesi sumber daya alam - degradasi lingkungan. Tetapi dalam prakteknya ditemui banyak kesulitan, dan kesulitan terbesar adalah pada pemberian nilai ekonomi (valuasi ekonomi) pada jasa lingkungan. Ada beberapa faktor yang menyebabkan hal tersebut, diantaranya :

a. Nilai lingkungan sangat beragam dan secara umum bersifat intangible;

b. Dampak lingkungan biasanya terjadi dalam jangka panjang;

c. Lingkungan dianggap sebagai barang publik (public good) atau sumber daya milik umum (common resource) sehingga hak kepemilikan (property right) tidak dapat didefinisikan dengan jelas;

d. Adanya aspek eksternalitas (negative) pada lingkungan.

\subsection{Konsep Nilai Ekonomi Sumberdaya Alam}

Sumber daya alam dan lingkungan (SDAL) sudah lama dan seringkali tidak diberi nilai atau kalaupun diberi dengan nilai sangat murah. Sehingga usaha-usaha yang dilakukan untuk mempertahankan cadangan SDAL seringkali tidak dilaksanakan, dan justru eksploitasi SDAL secara berlebihan terus terjadi. Penentuan nilai atau harga terhadap SDAL merupakan esensi atau pokok dari ekonomika lingkungan. Tanpa kita dapat memberikan nilai terhadap lingkungan baik yang berupa manfaat ataupun berupa kerugian atau kerusakan, maka usaha-usaha kita dalam mengelola lingkungan sulit untuk dikatakan efisien atau tidak efisien. Oleh karenanya diperlukan suatu persepsi yang sama untuk penilaian atau valuasi SDAL tersebut. Salah satu tolok ukur yang 
relatif mudah dan bisa dijadikan persepsi bersama antara berbagai disiplin ilmu adalah dengan memberikan "price tag" (harga) terhadap barang dan jasa yang dihasilkan dari SDAL. Dengan demikian kita menggunakan apa yang disebut sebagai nilai ekonomi dari SDAL (Fauzi, 2004). Secara umum nilai ekonomi SDAL didefinisikan sebagai pengukuran jumlah maksimum seseorang ingin mengorbankan barang dan jasa untuk memperoleh barang dan jasa lainnya. Konsep ini disebut sebagai keinginan membayar (willingness to pay) seseorang terhadap barang dan jasa yang dihasilkan oleh sumber daya alam dan lingkungan. Dengan menggunakan pengukuran ini, nilai ekologis dari SDAL bisa diartikan ke dalam bahasa ekonomi dengan mengukur nilai moneter dari barang dan jasa. Nilai merupakan persepsi manusia tentang makna suatu objek bagi individu tertentu pada tempat dan waktu tertentu (Nurfatriani, 2006). Beckermen, (1992) dalam United Nation Development Programme - UNDP dan Convention on Biological Diversity - CBD (United Nations Statistical Office (UNSO), 2000) menuliskan bahwa nilai ekonomi didasarkan pada preferensi manusia, semua jenis motivasi dapat terjadi sebagai faktor penentu suatu preferensi, dan motivasi tersebut dapat berupa nilai intrinsik, sosial, budaya, dan nilai spiritual.

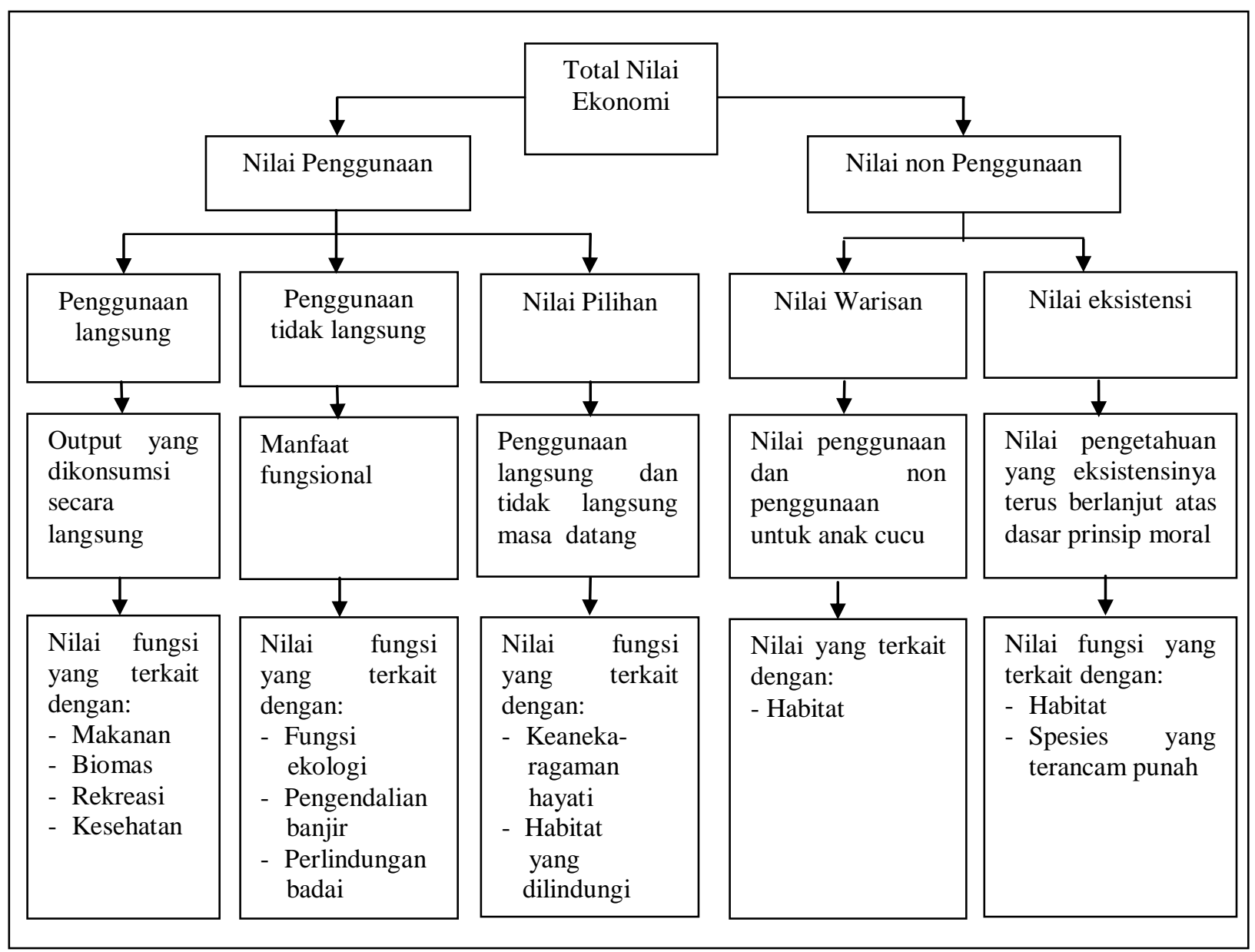

Diagram 2. Klasifikasi Nilai Sumberdaya Alam

Sumber : Muaningshe, (1993) 


\subsubsection{Valuasi Ekonomi}

Valuasi ekonomi sangat berguna untuk mengubah informasi fisik menjadi informasi moneter. Nilai moneter dapat mengetahui nilai pengorbanan SDAL untuk menciptakan nilai tambah tertentu. Tanpa mengubah volume deplesi sumber daya alam menjadi nilai moneter hal tersebut tidak mungkin diperoleh nilai dari deplesi tersebut. Demikian pula dengan diketahuinya nilai cadangan dan kemudian dibandingkan dengan nilai PDB/PDRB, maka akan dapat diketahui potensi cadangan tersebut dalam menopang pertumbuhan ekonomi.

Tujuan utama dari valuasi ekonomi adalah untuk menentukan preferensi seseorang dengan melihat kesediaan untuk membayar (willingness to pay/WTP) terhadap manfaat yang diperoleh dari suatu barang atau sumber daya. Penelitian ini menggunakan dua model matematis, yaitu untuk mengestimasi biaya ekonomi deforestasi dan untuk mengestimasi kontribusi deforestasi terhadap PDB subsektor kehutanan. Untuk mengestimasi biaya ekonomi deforestasi di Indonesia digunakan model matematika nilai ekonomi total yang didasarkan pada (Muaningshe, 1993; Pearce \& Turner, 1990) dalam (Alam, Supratman, \& KS, 2009) sebagai berikut:

$$
T E V=U V+N U V=(D U V+I U V)+(O V+E V)
$$

Model matematika yang digunakan untuk mengestimasi kontribusi deforestasi terhadap PDB sektor kehutanan seperti yang dipublikasikan oleh Yusuf (2010) dengan penyesuaian yaitu:

$P D R H=P D B$ sub sektor kehutanan $-D R-D L$

Di mana PDRH adalah Produk Domestik Hijau. PDB sub sektor kehutanan merupakan nilai PDB yang diperoleh dalam PDB dengan pendekatan produksi sektor pertama sub sektor ke empat. DR merupakan depresiasi pada sumber daya alam yang digunkan atau biasa disebut deplesi. DL merupakan degradasi lingkungan yang terjadi.

\subsection{Tinjauan Empiris}

Studi yang terkait dengan menghitung nilai ekonomi deforestasi sudah banyak dilakukan di beberapa negara, yaitu oleh Damnyag, Tayynela, Appiah, Saastamoinen, \& Pappinen, (fcost2011) di Ghana, (Sutcliffe, 2009) di Ethiopia bagian barat daya, (Torras, 2000) di wilayah Amazon, dan (Andersen, 1997) di Brazil. Penelitian-penelitian tersebut menghitung biaya dan manfaat deforestasi, kemudian membuat analisis manfaat-biaya (Cost Benefit Analysis - CBA) dari deforestasi. Instrumen valuasi ini pada saranya lebih menitikberatkan pada aspek ekonomi dalam perspektif jangka pendek tanpa memperhitungkan dampak eksternalitas kerusakan lingkungan akibat konversi hutan (Yani, 2015).

Arim (2011) dalam (Kusnawaty, 2013: 16) melakukan penelitian dengan mengidentifikasi sumber daya alam yang dimanfaatkan oleh sub sektor tanaman bahan makanan di Kabupaten Jayapura. Pada intinya tujuan penelitian ini untuk mengetahui nilai deplesi sumber daya alam dan kerusakan (degradasi) lingkungan akibat kegiatan sub sektor ini ; mengetahui perbedaan kontribusi sebelum dan sesudah perhitungan kontribusi hijau sub sektor ini dan mengetahui faktor-faktor yang berpengaruh terhadap PDRB Hijau sub sektor tanaman bahan makanan. Metode analisis yang digunakan adalah tabulasi, analisis trend LQ (Location Quotiont) dan analisis regresi. Hasil penelitian yaitu (1) sumber daya tanah telah dimanfaatkan $6 \%$ dari total potensi lahan tanaman pangan dan hortikultura, sumber daya air belum teridentifikasi karena keadaan irigasi yang tidak memadai. (2) Sub sektor tanaman bahan makanan masih 
merupakan sub sektor basis yang memiliki keunggulan komparatif (rata-rata LQ>1) dengan Trend peranan yang mengalami perubahan setiap tahun dan cenderung menurun. (3) nilai deplesi lahan setiap tahun adalah Rp.29.613.731.000,- dan nilai degradasi tanah setiap tahun Rp.19.516.500.000,-. (4) setelah perhitungan kontribusi hijau nilai kontribusi PDRB Sub Sektor Tanaman Bahan Makanan pada PDRB Kabupaten Jayapura menurun sebesar Rp.49,13 miliar rupiah. (5) faktor yang signifikan berpengaruh terhadap PDRB Hijau Sub Sektor Tanaman Bahan Makanan adalah Program Gerakan Wajib Tanam Kakao.

Thahir, (2010) dalam Kusnawaty, (2013: 36) meneliti besarnya perambahan hutan yang terjadi di Sulawesi Selatan serta akibat lanjutannya seperti degradasi yang diukur dengan banjir dan kekeringan, sehingga dampak banjir maupun kekeringan terhadap lahan-lahan pertanian produktif dapat diketahui. Metode yang digunakan untuk mencapai tujuan penelitian adalah metode survey terutama untuk mengetahui penyebab perambahan hutan, penghitungan luas hutan yang terdeplesi, luas lahan pertanian dan perikanan yang mengalami degradasi, serta penghitungan biaya konservasi dengan willingness to pay (kesediaan untuk membayar). Selain itu dalam penelitian ini diterapkan metode pemantauan kerusakan lahan melalui GIS (Geographical Information System). Hasil penelitian ini mendapatkan bahwa kawasan hulu sungai pada 3 (tiga) lokasi, yaitu hulu sungai Saddang di Kabupaten Tana Toraja, hulu sungai Bila di Kabupaten Enrekang serta hulu sungai Jeneberang di Kabupaten Gowa, mengalami deplesi sehingga wilayah tersebut merupakan lahan kritis. Bahkan, di hulu sungai Jeneberang 47\% dari seluruh wilayah hutan merupakan lahan yang sangat kritis; sedangkan di hulu sungai Saddang yang berlokasi di Tana Toraja, hanya 37\% lahan yang tidak kritis. Salah satu penyebab dari deplesi hutan di Tana Toraja ini adalah eksploitasi hasil hutan, disamping adanya lokasi pertambangan emas di daerah hutan lindung dan hutan konservasi. Tanda-tanda degradasi juga terjadi, dimana beberapa sungai sudah mengalami penurunan debit air bahkan kekeringan.

\section{METODA PENELITIAN}

Penelitian ini menggunakan metode deskriptif dengan pendekatan kuantitatif, dengan wilayah penelitian di wilayah administrasi Kalimantan Barat serta periode waktu tahun 2009 sampai dengan tahun 2015. Objek penelitian ini adalah terkait dengan nilai deforestasi yang terjadi di Kalimantan Barat. Dalam kontes ini, maka populasi penelitian ini adalah nilai deforestasi yang terjadi di Kalimantan Barat. Data yang digunakan dalam penelitian ini adalah data sekunder berupa data runtut waktu (time series) selama periode 2009 hingga 2015. Untuk memperoleh biaya ekonomi deforestasi di Kalimantan Barat nilai didapatkan dengan cara metode benefit transfer dari laporan yang dipublikasikan oleh Food and Agricultural Organization FAO (2009:74). Laporan FAO tersebut menyajikan nilai ekonomi dari hutan Indonesia pada tahun 2002 dalam satuan US\$ per hektar, termasuk dalam hal ini nilai hutan yang ada di Kalimantan Barat.

Nilai yang digunakan untuk benefit transfer dalam penelitian ini yaitu nilai yang berasal dari working paper dengan judul Indonesia Forestry Outlook Study yang ditulis FAO (Food and Agriculture Organization, 2010). Nilai ekonomi hutan Indonesia ini bersumber dari Bappenas (Badan Perencanaan Nasional), kemudian dijadikan dalam satuan rupiah per hektar per tahun dengan mengalikan nilai Dollar Amerika dengan kurs rupiah terhadap Dollar pada tahun 2002 yaitu sebesar Rp 9.311,2 per Dollar. Untuk mengestimasi kerugian biaya ekonomi akibat 
deforestasi pada masing-masing jenis nilai dari tahun 2009 hingga 2015, penelitian ini menggunakan hasil masing-masing nilai dari fungsi hutan tahun 2002 dikalikan dengan luas areal deforestasi tahun yang diteliti dan dikalikan dengan nilai kurs Dollar Amerika terhadap Rupiah tahun berjalan.

Tabel 1. Nilai Ekonomi Hutan Indonesia Per Hektar Tahun 2002 (US \$)

\begin{tabular}{|c|c|c|c|c|c|c|}
\hline \multirow[t]{2}{*}{ NO. } & \multirow[t]{2}{*}{ Nilai Ekonomi } & \multicolumn{4}{|c|}{ Tipe Hutan } & \multirow{2}{*}{$\begin{array}{l}\text { Total } \\
\text { Nilai } \\
\text { Ekonomi }\end{array}$} \\
\hline & & $\begin{array}{l}\text { Hutan } \\
\text { Produksi } \\
\text { Primer } \\
\end{array}$ & $\begin{array}{l}\text { Hutan } \\
\text { Produksi } \\
\text { Sekunder } \\
\end{array}$ & $\begin{array}{l}\text { Hutan } \\
\text { Konservasi }\end{array}$ & $\begin{array}{l}\text { Hutan } \\
\text { Lindung }\end{array}$ & \\
\hline 1 & Nilai Guna & & & & & \\
\hline 1.1 & Nilai Guna Langsung & 109,73 & 93,02 & 135,09 & 135,09 & 472,93 \\
\hline 1.2 & Nilai Guna Tak Langsung & 90,11 & 102,46 & 116,46 & 116,46 & 425,49 \\
\hline 2 & Nilai Bukan Guna & & & & & \\
\hline 2.1 & Nilai Pilihan & 3,4 & 2,95 & 7,58 & 7,58 & 21,51 \\
\hline 2.2 & Nilai Eksistensi & 6,19 & 4,64 & 10,35 & 10,35 & 31,53 \\
\hline & Total Nilai Ekonomi & 209,43 & 203,07 & 269,48 & 269,48 & 951,46 \\
\hline
\end{tabular}

Berikut rumus perhitungan nilai kerugian ekonomi masing-masing fungsi dari kawasan hutan di Kalimantan Barat:

NKEmfhn $=($ NKEmfh2002 per ha $) x($ LDmfhn $) x($ NTKn $)$

Di mana,

NKEmfh $=$ Nilai Kerugian Ekonomi Masing-masing fungsi Hutan tahun ke $\mathrm{n}$.

NKEmfh2002 = Nilai Kerugian Ekonomi Masing-masing fungsi hutan tahun 2002.

LDmfhn = luas deforestasi masing-masing fungsi hutan tahun ke $\mathrm{n}$

NTKn $\quad=$ Nilai tukar kurs Dollar Amerika terhadap Rupiah pada tahun ke $\mathrm{n}$

Perhitungan nilai ekonomi dilakukan dengan menjumlahkan seluruh nilai manfaat yang dimiliki sumber daya hutan. Seluruh nilai tersebut diklasifikasikan ke dalam dua nilai, nilai guna (use value) yang terdiri dari nilai kayu, nilai kayu bakar, nilai hutan bukan kayu, dan nilai konsumsi air yang selanjutnya dikelompokkan dalam nilai penggunaan langsung (direct use value) serta nilai konservasi tanah dan air, nilai serapan karbon, nilai pencegah banjir, nilai transportasi air, dan nilai keanekaragaman hayati yang dikelompokkan dalam nilai penggunaan hutan tidak langsung (indirect use value) dan nilai bukan guna (non-use value) yang terdiri dari nilai pilihan dan nilai keberadaan.

$$
\begin{aligned}
& T E V=f(D U V, I U V, O V, E V) \ldots \ldots \ldots \ldots \ldots \ldots \ldots \ldots \ldots \ldots \ldots \ldots \ldots \ldots \ldots \ldots \ldots \ldots \\
& T E V=U V+N U V \ldots \ldots \ldots \ldots \ldots \\
& T E V=(D U V+I U V+O V)+(B V+E V) \\
& \text { Di mana } \\
& \mathrm{TEV} \quad=\text { Total Ekonomi Value } \\
& \mathrm{DUV}=\text { Direct Use Value } \\
& \mathrm{IUV} \quad=\text { Indirect Use Value }
\end{aligned}
$$




$$
\begin{array}{ll}
\mathrm{OV} & =\text { Option Value } \\
\mathrm{EV} & =\text { Existence Value } \\
\mathrm{UV} & =\text { Use Value } \\
\mathrm{NUV} & =\text { Non Use Value } \\
\mathrm{BV} & =\text { Bequest Value }
\end{array}
$$

Dalam PDRB konvensional terdapat sembilan sektor kegiatan ekonomi dengan masingsektor dibagi lagi ke dalam sub-sektor. Subsektor kehutanan merupakan bagian dari sektor pertanian. Dalam konteks penelitian ini, untuk menyusun PDRB hijau dari sumber daya hutan, dapat dilihat di sektor pertanian pada subsektor ke empat yaitu kehutanan. Dari nilai PDRB subsektor kehutanan dikurangi biaya input antara. Hasil dari pengurangan ini disebut dengan nilai tambah. Kemudian nilai tambah yang ada dikurangi lagi dengan nilai deplesi dan nilai degradasi yang selanjutnya disebut dengan kontribusi semi hijau dan kontribusi hijau pada PDRB. Secara matematis, persamaan untuk memperoleh nilai PDRB hijau ditulis pada persamaan 7 sebagai berikut:

PDRBH=PDRB SUBSEKTOR KEHUTANAN - NILAI KERUSAKAN LINGKUNGAN (7)

Di mana kerusakan lingkungan dibagi menjadi dua jenis, yakni deplesi dan degradasi, sehingga secara matematis kerusakan lingkungan dapat diestimasi dengan menggunakan persamaan berikut ini:

$$
\begin{aligned}
& \text { NILAI KERUSAKAN LINGKUNGAN = NILAI DEPLESI + NILAI DEGREDASI.......(8) } \\
& \text { NILAI DEPLESI = NILSI GUNA EKSTRATIF X LUAS DEFORESTASI...................(9) } \\
& \text { NILAI DEGRADASI = NILAI GUNA NON EKSTRATIF X LUAS DEFORESTASI......(10) }
\end{aligned}
$$

\section{HASIL PENELITIAN DAN PEMBAHASAN}

\subsection{Perkiraan Nilai Ekonomi Deforestasi Hutan Produksi Primer}

Hutan produksi primer adalah salah satu kawasan hutan yang mengalami deforestasi. Berdasarkan hasil perhitungan menunjukkan bahwa selama 7 (tujuh) tahun yaitu dari tahun 2009 sampai dengan 2015, total nilai kerugian ekonomi dari deforestasi pada kawasan hutan ini adalah sebesar $\mathrm{Rp} 410.476 .500 .943,-$, dimana rata-rata pertahun nilai kerugian ekonomi akibat dari deforestasi selama periode tersebut mencapai angka sebesar Rp. 58.639.500.135,-. Bila dicermati angka per tahun, pada tahun 2009 nilai kerugian ekonomi akibat deforestasi pada hutan produksi primer ini mencapai angka Rp. 15.889.739.446,- dan terus menurun selama 2 (dua) tahun berikutnya. Hal ini dapat dilihat pada tahun 2010, nilai kerugian ekonomi dari deforestasi turun menjadi sebesar Rp. 14.009.196.513,-, sedangkan tahun 2011 nilai kerugian ekonomi turun lagi menjadi Rp. 13.884.238.368,-. Penurunan nilai kerugian ekonomi dari deforestasi ini, bukan faktor bekurangnya deforestasi, bahkan angka deforestasi selama tahun 2009 sampai dengan 2011 tidak mengalami perubahan, namun hal ini karena terjadi perubahan dari nilai mata uang Rupiah terhadap mata uang Dollar Amerika Serikat yang semula pada tahun 2009 nilai tukar 1 US\$ sebesar Rp 10.300, secara berturut-turut tahun 2010 turun menjadi Rp 9.081,- dan tahun 2011 turun lagi meenjadi Rp. 9.000,-. Berbeda dengan 3 (tiga) tahun sebelumnya, pada tahun 
2012 terjadi kenaikan nilai kerugian ekonomi dari deforestasi yang sangat signifikan dengan mencapai angka sebesar Rp 150.106.472.858,-. Kenaikan ini, disebabkan oleh 2 (dua) faktor, yaitu : (1) meningkatnya angka deforestasi dan (2) meningkatkannya nilai tukar mata uang Dollar Amerika terhadap mata uang Rupiah.

Tabel 2. Perkiraan Nilai Ekonomi Deforestasi Hutan Produksi Primer di Kalimantan Barat Tahun 2009-2015 dengan Tahun Dasar 2002 (Nilai US \$/ HA Tahun 2002)

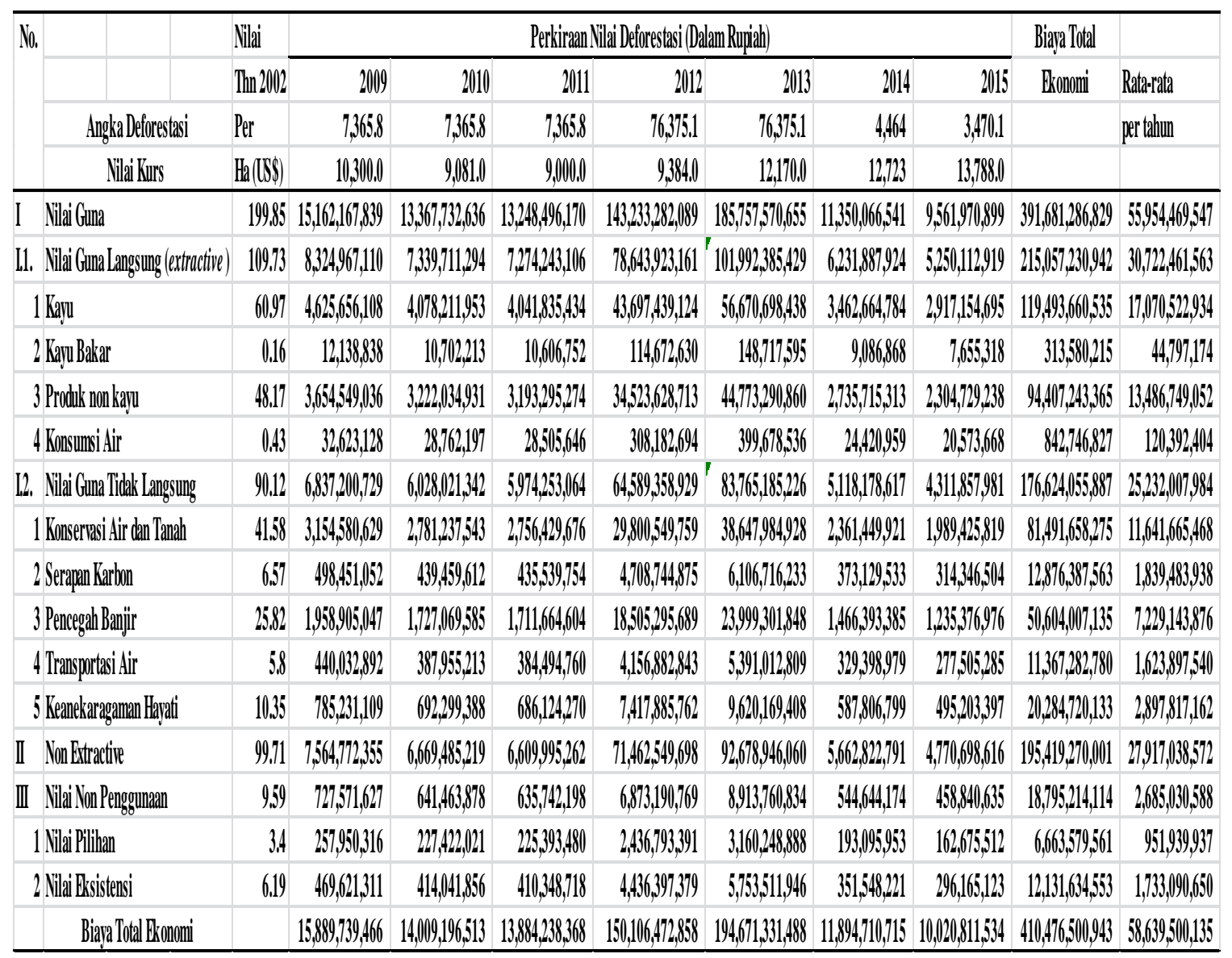

Pada tahun 2013 nilai kerugian ekonomi dari deforestasi terus mengalami peningkatan bahkan lebih besar dibandingkan dengan tahun 2012, yaitu mencapai angka $\mathrm{Rp}$ 194.671.331.488,-,. Peningkatan nilai kerugian ekonomi dari deforestasi tahun 2013 ini, bukan disebabkan oleh meningkatkannya angka deforestasi, karena luasan angka deforestasi tahun 2012 dan 2013 adalah sama. Namun kenaikan nilai kerugian ekonomi ini dikarenakan kenaikan nilai tukar mata uang Dollar Amerika terhadap nilai mata uang Rupiah. Setelah mengalami kenaikan selama 2 (dua) tahun sebelumnya, pada tahun 2014 dan 2015, angka nilai kerugian ekonomi dari deforestasi mengalami penurunan. Penurunan nilai kerugian ini bukan karena faktor menurunnya nilai tukar mata uang Dollar Amerika terhadap nilai mata uang Rupiah, justru sebaliknya nilai tukar mata uang Dollar Amerika terhadap nilai mata uang Rupiah mengalami kenaikan. Faktor penyebabkan menurunnya nilai kerugian ekonomi dari deforestasi pada tahun 2014 dan tahun 2015, adalah karena menurunnya luasan angka deforestasi. Tahun 2014 nilai kerugian ekonomi dari deforestasi turun menjadi Rp 11.894.710.715,-. Penurunan nilai kerugian ekonomi dari deforestasi ini, karenakan terjadinya penurunan yang signifikan angka luasan deforestasi pada tahun 2014 yang turun menjadi hanya 4.464 ha. Hal yang sama terjadi pada nilai kerugian 
ekonomi dari deforestasi tahun 2015 yang mengalami penurunan menjadi Rp 10.020.811.534,-. Penurunan ini juga terjadi karena berkurangnya luasan angka deforestasi pada tahun 2015 yang hanya mencapai angka 3.470 ha. Berikut ini tabel yang menyajikan data nilai ekonomi deforestasi pada kawasan hutan produksi primer di Kalimantan Barat tahun 2009-2015.

\subsection{Perkiraan Nilai Ekonomi Deforestasi Hutan Produksi Sekunder}

Hasil perhitungan dari total nilai kerugian ekonomi akibat deforestasi yang terjadi pada hutan produksi sekunder selama periode tahun 2009- 2015 mendapatkan angka yang sangat massive yaitu Rp 1.071.061.461.085,. Sementara itu, rata-rata pertahun nilai kerugian ekonomi akibat dari deforestasi yang terjadi pada hutan ini selama periode 2009 sampai dengan 2015 adalah sebesar Rp. 153.008.780.155,-. Jika dilihat per tahunnya menunjukkan bahwa pada tahun 2009 total kerugian ekonomi akibat dari deforestasi pada hutan sekunder ini mencapai angka sebesar Rp. 70.627.138.821,-. Namun pada tahun 2010, nilai kerugian mengalami penurunan, disebabkan oleh penurunan pada nilai kurs rupiah terhadap Dollar Amerika Serikat yang memberikan implikasi terhadap penurunan nilai kerugian ekonomi deforestasi menjadi sebesar Rp 62.268.451.226,-. Fenomena yang sama terjadi pula pada tahun 2011, dimana nilai kerugian ekonomi akibat deforestasi lebih rendah dibandingkan dengan tahun 2010, sekalipun angka luasan deforestasinya sama. Dengan kurs yang relative lebih rendah maka nilai kerugian ekonomi akibat deforestasi pada tahun 2011 turun menjadi sebesar Rp. 61.713.033.921,-. Berbeda dengan tahun 2011, pada tahun 2012 nilai kerugian ekonomi akibat deforestasi pada hutan produksi sekunder di Kalimantan Barat mengalami kenaikan yang sangat signifikan yaitu mencapai angka sebesar Rp 312.848.002.169,-.

Ada 2 (dua) faktor yang menyebabkan kenaikan nilai kerugian ekonomi ini yaitu : (1) meningkatnya angka deforestasi dan (2) meningkatkannya nilai tukar mata uang Dollar Amerika terhadap mata uang Rupiah. Sementara itu jika dibandingkan dengan tahun 2012, meskipun angka deforestasi tahun 2013 sama besar dengan tahun 2012, namun nilai kerugian ekonmi akibat deforestasi tahun 2013 lebih tinggi dengan nilai sebesar Rp 405.728.920.119,-. Kenaikan nilai kerugian ekonomi akibat deforestasi tahun 2013 ini dipicu oleh naiknya nilai tukar mata uang Dollar Amerika terhadap nilai mata uang Rupiah yang cukup massive. Setelah mengalami kenaikan selama 2 (dua) tahun berturut-turut, pada tahun 2014 nilai kerugian ekonomi akibat deforestasi mengalami penurunan yang ekstrim dan signifikan, sekalipun nilai tukar mata uang Dollar Amerika terhadap mata uang rupiah relative stabil. Penurunan ini karena angka deforestasi pada tahun 2014 mengalami penurunan yang sangat drastis dengan luas sebesar 22.263 ha. Dampak dari penurunan angka deforestasi ini telah menjadikan nilai kerugian ekonomi akibat deforestasi pada kawasan hutan produksi sekunder tahun 2014 hanya sebesar Rp 57.520.013.897,-. Namun pada tahun 2015 dengan adanya kebijakan pemerintah memberikan relaksasi atas pemberian ijin baru pembukaan lahan perkebunan kelapa sawit dengan ketentuan dan syarat-syarat yang sangat ketat, diduga telah memberikan dampak terjadinya peningkatan angka deforestasi di kawasan hutan produksi sekunder di seluruh Indonesia termasuk juga yang ada di Kalimantan Barat yang mencapai angka 35.842 ha. Selain itu, pada saat yang sama terjadi kenaikan nilai tukar Dollar Amerika terhadap rupiah yang cukup signifikan mendorong kenaikan dari nilai kerugian ekonomi akibat deforestasi pada tahun 2015 menjadi sebesar Rp 100.355.900.931. Berikut tabel 3 yang menyajikan data perkiraan nilai ekonomi deforestasi pada hutan sekunder di Kalimantan Barat tahun 2009-2015. 
Tabel 3. Perkiraan Nilai Ekonomi Deforestasi Hutan Produksi Sekunder di Kalimantan Barat Tahun 2009-2015 dengan Tahun Dasar 2002 (Nilai US \$/ha Tahun 2002)

\begin{tabular}{|c|c|c|c|c|c|c|c|c|c|c|c|}
\hline \multirow[t]{4}{*}{ No. } & & \multirow{2}{*}{\begin{tabular}{|l|} 
Nilai \\
Thn2002
\end{tabular}} & \multicolumn{7}{|c|}{ Perkiraan Nilai Deforestasi (Dalam Rupiah) } & & \multirow[b]{2}{*}{ Rata-rata } \\
\hline & & & 2009 & 2010 & 2011 & 2012 & 2013 & 2014 & \multicolumn{2}{|c|}{2015 Biaya Total } & \\
\hline & Angka Deforestasi & Per & 33,767 & 33,767 & 33,767 & 164,172 & 164,172 & 22,263 & \multirow{2}{*}{\multicolumn{2}{|c|}{ 35,842 Ekonomi }} & \multirow[t]{2}{*}{ per tahun } \\
\hline & Nilai Kurs & $\mathrm{Ha}($ ISS) & 10,300 & 9,081 & 9,000 & 9,384 & 12,170 & 12,723 & & & \\
\hline I & Nilai Guna & 195.48 & $67,987,359,515$ & $59,941,088,520$ & $59,406,430,644$ & $301,154,909,460$ & $390,564,284,754$ & $55,370,130,087$ & $96,604,971,262$ & $1,031,029,174,240$ & $147,289,882,034$ \\
\hline L1. & . Nilai Guna Langsung (extractive) & 93.02 & $32,352,077,870$ & $28,523,225,159$ & $28,268,805,906$ & $143,305,860,845$ & $185,851,697,195$ & $26,348,114,900$ & $45,969,891,686$ & $490,619,673,562$ & $70,088,524,795$ \\
\hline & 1 Kayu & 53.67 & $18,666,265,527$ & $16,45,122,063$ & $16,310,329,101$ & $82,683,566,004$ & $107,231,354,424$ & $15,202,142,837$ & $26,523,372,251$ & $283,074,154,806$ & $40,439,164,972$ \\
\hline & 2 Kayu Bakar & 0.16 & $55,647,522$ & $4,061,664$ & $48,624,448$ & $246,494,708$ & $319,676,108$ & $45,320,34$ & $79,070,981$ & $843,895,375$ & $120,556,482$ \\
\hline & 3 Produk non kayu & 38.76 & $13,480,612,108$ & $11,885,188,209$ & $11,79,175,628$ & $59,713,343,005$ & $77,41,537,124$ & $10,978,853,295$ & $19,154,45,192$ & $204,433,654,561$ & $29,204,807,994$ \\
\hline & 4 Konsumsi Air & 0.43 & $149,552,714$ & $131,853,223$ & $130,677,129$ & $662,454,528$ & $859,129,540$ & $121,798,424$ & $212,503,262$ & $2,267,968,820$ & $323,995,546$ \\
\hline & Nilai Guna Tidak Langsung & 102.46 & $35,635,281,645$ & $31,417,863,361$ & $31,137,624,738$ & $157,849,048,611^{\prime}$ & $204,712,587,558$ & $29,022,015,187$ & $50,635,079,576$ & $540,409,500,679$ & $77,201,357,240$ \\
\hline & 1 Konservasi Airdan Tanah & 40.12 & $13,553,616,041$ & 12,302,212,356 & 12,192,480,036 & $61,808,44,023$ & $80,158,78,041$ & $11,364,076,218$ & $19,827,44,532$ & $211,606,765,247$ & $30,229,337,892$ \\
\hline & 2 Serapan Karbon & 27.38 & $9,522,682,134$ & $8,395,677,326$ & $8,320,700,214$ & $42,181,406,901$ & $54,704,573,554$ & $7,755,443,440$ & $13,311,021,655$ & $144,411,596,024$ & $20,630,228,003$ \\
\hline & 3 Pencegah Banjir & 24.52 & $8,527,92,685$ & $7,718,700,074$ & $7,451,635,356$ & $37,75,313,996$ & $48,90,363,526$ & $6,945,342,693$ & $12,117,627,866$ & $129,326,966,198$ & $18,475,280,885$ \\
\hline & 4 Transportasi Air & 5.8 & $2,017,222,658$ & $1,778,485,336$ & $1,762,261,740$ & $8935,433,164$ & $11,588,258,909$ & $1,442,862,464$ & $2,866,323,068$ & $30,591,207,339$ & $4,370,172,477$ \\
\hline & 5 Keanekaragamaman Hayati & 4.64 & $1,113,778,126$ & $1,422,788,269$ & $1,410,097,392$ & $7,148,346,531$ & $9,270,007,127$ & $1,314,289,971$ & $2,293,058,454$ & $24,472,965,871$ & $3,496,137,982$ \\
\hline & Non Extractive & 110.05 & $38,275,060,951$ & $33,745,226,067$ & $33,444,228,015$ & $169,542,141,324$ & $219,877,222,924$ & $31,171,898,997$ & $54,386,009,246$ & $580,441,787,524$ & $82,920,255,361$ \\
\hline & Nilai Non Pengggunaan & 7,59 & $2,639,779,306$ & $2,327,362,706$ & $2,306,603,277$ & $11,693,092,709$ & $15,164,635,366$ & 2,149,883,811 & $3,750,929,670$ & $40,032,286,845$ & $5,718,898,121$ \\
\hline & 1 Niliai Pilithan & 2.95 & $1,026,000,180$ & $904,574,438$ & $896,050,885$ & $4,54,746,178$ & $5,89,028,238$ & $835,593,840$ & $1,45,871,216$ & $15,559,320,974$ & $2,222,760,139$ \\
\hline & 2 Nilai Eksistensi & 4.64 & $1,013,778,126$ & $1,422,788,269$ & $1,410,097,392$ & $7,148,346,531$ & $9,270,007,127$ & $1,314,289,971$ & $2,293,058,454$ & $24,472,965,871$ & $3,496,137,982$ \\
\hline \multicolumn{3}{|c|}{ Biaya Total Ekonomi } & $70,627,138,821$ & $62,268,451,226$ & $61,713,033,921$ & $312,848,002,169$ & $405,728,920,119$ & $57,520,013,897$ & $100,355,900,931$ & $1,071,061,461,085$ & $153,008,780,155$ \\
\hline
\end{tabular}

\subsection{Perkiraan Nilai Ekonomi Deforestasi Hutan Lindung}

Hasil perhitungan perkiraan nilai kerugian ekonomi akibat deforestasi pada kawasan hutan lindung di Kalimantan Barat selama 7 (tujuh) tahun yaitu dari tahun 2009 sampai dengan tahun 2015 adalah sebesar $\mathrm{Rp}$ 137.765.820.663,-, dengan rata-rata nilai kerugian ekonomi akibat deforestasi per tahun selama periode tersebut adalah sebesar Rp. 19.680.831.523,-. Namun jika dilihat pertahun, nilai kerugian ekonomi pada tahun 2009 mendapatkan angka sebesar Rp1.200.743.539,-. Tetapi nilai kerugian ekonomi akibat deforestasi ini menurun pada tahun 2010 dan 2011. Penurunan nilai kerugian ekonomi ini, karena nilai Kurs Dollar Amerika tahun 2010 dan 2011 yang lebih rendah dibandingkan tahun 2009, maka nilai kerugian ekonomi akibat deforestasi pada hutan lindung tahun 2010 adalah turun menjadi sebesar Rp 1.058.636.173,-. Selanjutnya pada tahun 2011 kurs Dollar Amerika turun menjadi 1 US\$ = Rp 9.000,-, maka sejalan dengan turunnya nilai mata uang Amerika tersebut, maka nilai kerugian ekonomi akibat deforestasi tahun 2011 turun menjadi sebesar Rp1.049.193.432,-.

Berbeda dengan tahun 2011, Pada tahun 2012 nilai kerugian ekonomi mengalami kenaikan yang sangat mencolok sekali. Faktor penyebab adalah: (1) meningkatnya angka deforestasi dan (2) meningkatkannya nilai tukar mata uang Dollar Amerika terhadap mata uang Rupiah, sehingga nilai kerugian ekonomi akibat deforestasi pada tahun 2012 menjadi Rp 53.394.860.117,-. Trend kenaikan nilai kerugian ekonomi akibat deforestasi juga terjadi pada tahun 2013 yang dipicu oleh kenaikan kurs Dollar Amerika, sehingga nilai kerugian ekonomi akibat deforestasi pada kawasan hutan lindung tahun 2013 naik menjadi Rp 69.247.170.463,-. Kenaikan nilai kerugian ekonomi akibat deforestasi tahun 2013, tidak diikuti oleh nilai kerugian ekonomi akibat deforestasi pada 
tahun 2014 yang justru mengalami penurunan yang sangat drastic. Angka nilai kerugian ekonomi akibat deforestasi pada tahun 2014 turun menjadi Rp 8.509.084.688,-. Penurunan nilai kerugian ekonomi dari deforestasi ini, karena terjadinya penurunan yang signifikan angka luasan deforestasi. Sama seperti yang terjadi pada tahun 2014, nilai kerugian ekonomi akibat deforestasi tahun 2015 juga mengalami penurunan, sehingga nilai kerugian ekonomi pada tahun 2015 turun menjadi Rp 3.306.132.196,-. Berikut ini tabel yang menyajikan data yang terkait dengan nilai kerugan ekonomi akibat deforestasi pada kawasan hutan lindung di Kalimantan Barat tahun 2009 -2015 .

Tabel 4. Perkiraan Nilai Ekonomi Deforestasi Hutan Lindung di Kalimantan Barat Tahun 2009-2015 dengan Tahun Dasar 2002 (Nilai US \$/ha Tahun 2002)

\begin{tabular}{|c|c|c|c|c|c|c|c|c|c|c|c|}
\hline \multirow[t]{4}{*}{ No. } & & Nilai & \multicolumn{7}{|c|}{ Perkiraan Niliai Deforestasi (Dalam Rupiah) } & \multirow[b]{2}{*}{ Biagag Total } & \multirow[b]{2}{*}{ Ratar-rata } \\
\hline & & Thn 2002 & 2009 & 2010 & 2011 & 2012 & 2013 & 2014 & 2015 & & \\
\hline & Angka Deforestasi & Per & 433 & 433 & 433 & 21,115 & 21,115 & 2,482 & 890 & Ekonomi & per tahun \\
\hline & Nilai Kurs & Ha (ISS) & 10,300 & 9,081 & 9,000 & 9,384 & 12,170 & 12,723 & 13,788 & & \\
\hline I & Vilai Guna & 251,55 & $1,120,851,459$ & $988,199,233$ & $979,384,770$ & $49,842,203,3,34$ & $64,639,771,993$ & $7,942,298,059$ & $3,086,156,872$ & $128,599,49,021$ & $18,371,356,574$ \\
\hline L1. & Nilai Guna Langsung (extractive) & 135.08 & $601,886,762$ & $530,653,756$ & $525,920,472$ & $26,764,797,796$ & $34,710,953,637$ & $4,46,278,164$ & $1,057,237,409$ & $69,056,727,976$ & 9,$865 ; 246,854$ \\
\hline & Kayu & 0 & & & & & & & & & \\
\hline & Kayu Bakar & 0 & & & & & & & & & \\
\hline & Produknon kayu & 28.47 & $126,856,057$ & $111,82,704$ & $10,85,098$ & $5,641,05,616$ & $7,15,8,19,145$ & $898,967,052$ & $349,285,92$ & $14,544,61,613$ & $2,079,238,806$ \\
\hline & KonsumsiAir & 106.61 & $475,030,706$ & $418,81,1,52$ & $415,05,374$ & $21,123,742,159$ & $27,395,13,492$ & $3,366,311,113$ & $1,307,951,477$ & $54,020,056,3,34$ & $7,786,008,048$ \\
\hline & Nilia Gunn Tiak Langsung & 116.47 & $518,964,697$ & $457,445,777$ & $453,464,498$ & $23,077,40,9,959$ & $29,928,818,457$ & $3,677,649,895$ & $1,428,919,463$ & $59,542,76,94$ & $8,506,109,721$ \\
\hline & Konservasi Airdan Tanah & 41.58 & $185,27,132$ & $163,34,560$ & $161,887,572$ & $8,238,675,537$ & $10,684,642,2,80$ & $1,312,297,643$ & $510,126,825$ & $21,256,875,530$ & $3,336,696,007$ \\
\hline & Serapan Karbon & 5.48 & $24,47,674$ & $21,27,554$ & $21,35,832$ & $1,085,809,000$ & $1,408,173,127$ & $173,036,159$ & $67,231,72$ & 2,801,531,458 & $400,218,780$ \\
\hline & Pencegah Banjir & 53.26 & $237,34,4843$ & 20,228,746 & $207,362,484$ & $10,52,54,74,764$ & 13,686,003,781 & $1,681,734,639$ & $653,423,633$ & $27,228,02,2,900$ & $3,889,117,556$ \\
\hline & Transpotatasi Air & 5.8 & $25,845,524$ & $2,784,955$ & $22,581,720$ & $1,1,4,214,000$ & $1,40,402,214$ & $183,140,400$ & $71,157,662$ & $2,965,124,336$ & $423,59,219$ \\
\hline & Keanekaragagman Hayati & 10.35 & $46,17,323$ & $40,599,360$ & $40,20,690$ & $2,050,752,59$ & $2,65,9597,055$ & $326,810,993$ & $126,979,621$ & $5,211,213,611$ & $755,887,659$ \\
\hline & Non Extractive & 134.4 & $598,856,832$ & $527,982,417$ & $523,7129,960$ & $26,630,062,341$ & $34,36,216,62,26$ & $4,243,806,524$ & $1,048,894,787$ & $68,709,092,686$ & $9,815,584,699$ \\
\hline & Vilai Non Pengggunaan & 17.93 & $79,892,135$ & $70,336,440$ & $69,808,602$ & $3,552,656,382$ & $4,007,398,569$ & $566,156,629$ & $219,975,324$ & $9,166,324,642$ & $1,30,774,49$ \\
\hline & NilaiPitihan & 7.58 & $33,77,812$ & $29,77,500$ & $20,51,972$ & $1,501,903,814$ & $1,97,7001,514$ & $239,356,366$ & $92,995,703$ & $3,875,111,031$ & $533,587,290$ \\
\hline & Nikia Exsistr & 10.55 & $46,117,323$ & $40,599,360$ & $40,26,690$ & $2,050,752,569$ & $2,659,597,055$ & $326,810,993$ & $126,99,621$ & $5,291,213,611$ & $755,887,659$ \\
\hline & Biaga Total Ekonomi & & $1,200,74,594$ & $1,058,036,173$ & $1,449,193,432$ & $53,394,860,117$ & $69,447,170,463$ & $8,909,084,688$ & $3,306,132,196$ & $137,765,82,663$ & $19,680,831,523$ \\
\hline
\end{tabular}

\subsubsection{Perkiraan Nilai Ekonomi Deforestasi Hutan Konservasi}

Hasil perhitungan perkiraan nilai kerugian ekonomi akibat deforestasi pada kawasan hutan konservasi selama 7 (tujuh) tahun yaitu dari tahun 2009 sampai dengan 2015 menghasilkan angka sebesar Rp 73.743.673.240,-, dimana rata-rata nilai kerugian ekonomi akibat dari deforestasi yang terjadi pada hutan konservasi pertahun selama periode tersebut adalah sebesar Rp 10.534.810.463,-. Sementara itu apabila dilihat per tahunnya, berdasarkan atas hasil perhitungan, besarnya nilai kerugian ekonomi akibat terjadinya deforestasi di kawasan hutan konservasi pada tahun 2009 adalah sebesar Rp 479.631.283,-. Namun pada tahun 2010 nilai kerugian ekonomi akibat deforestasi ini mengalami penurunan sebesar Rp 422.867.154,-Penurunan nilai disebabkan terjadinya penurunan nilai kurs dollar terhadap rupiah. Hal yang sama juga terjadi pada tahun 2011, dikarenakan faktor turunnya nilai tukar mata uang Amerika 
terhadap rupiah, mendorong nilai kerugian ekonomi akibat deforestasi pada tahun 2011 turun menjadi sebesar Rp 419.095.296,--

Tabel 5. Perkiraan Nilai Ekonomi Deforestasi Hutan Konservasi di Kalimantan Barat Tahun 2009-2015 dengan Tahun Dasar 2002 (Nilai US \$/ha Tahun 2002)

\begin{tabular}{|c|c|c|c|c|c|c|c|c|c|c|c|}
\hline \multirow[t]{2}{*}{$\mathrm{N}_{0}$} & & \multirow{2}{*}{$\begin{array}{l}\text { lilai } \\
\text { Thn2002 }\end{array}$} & \multicolumn{7}{|c|}{ Perkirann Nilai Deforestasi (Dalam Rupiah) } & \multirow[b]{2}{*}{ Biagra Total } & \multirow[b]{2}{*}{ Ratar-vata } \\
\hline & & & 2009 & 2010 & 2011 & 2012 & 2013 & 2014 & 2015 & & \\
\hline & Angka Deforestasi & Per & 173 & 173 & 173 & 11,873 & 11,773 & 711 & 275 & Ekonomi & per talun \\
\hline & Nilai Kurs & Ha(CSS) & 10,300 & 9,081 & 9,000 & 9,384 & 12,170 & 12,723 & 13,788 & & \\
\hline & Nilia Guna & 251.55 & $447,718,752$ & $394,731,455$ & $391,210,560$ & $28,06,5171,105$ & $36,347,262,699$ & $2,275,854,679$ & $953,802,135$ & $68,837,097,385$ & בצני, \\
\hline & Vilal Guna Langssung (extructive) & 135,08 & $240,420,787$ & $211,967,104$ & $210,076,416$ & $15,449,977,599$ & '19;18,140,510 & $1,222,112,702$ & $512,182,836$ & $36,964,878,214$ & $5,880,696,888$ \\
\hline & 1 Kayu & 0 & & & & & & & & & \\
\hline & 2 Kayu Bakar & 0 & & & & & & & & & \\
\hline & 3 Produk non kayu & 28.47 & $50,672,0,45$ & $44,65,033$ & 276,54 & $3,171,993,409$ & $4,113,212,265$ & $257,57,551$ & 107,94,999 & 5,285 & $1,1, a, 00,100$ \\
\hline & 4 Konsumsi Air & 106.61 & 189,748,742 & $167,222,071$ & $165,799,82$ & $11,877,984,451$ & $15,401,419,306$ & $96,553,50$ & $44,233,137$ & $29,174,012929$ & $4,167,116,133$ \\
\hline & Nilia Guna Tidak Langsung & 116,47 & $207,297,965$ & $182,764,351$ & $181,134,144$ & $12,976,539,246$ & '16,829,122,189 & $1,053,741,978$ & $441,619,299$ & $31,872,219,171$ & $4,553,174,167$ \\
\hline & 1 Konservasis Airdan Tanah & 41.58 & $74,005,747$ & $65,27,223$ & $64,665,216$ & $4,632,647,988$ & $6,008,026,965$ & $376,18,786$ & $157,68,886$ & 11,378 & $1,025,491,387$ \\
\hline & 2 Serapan Karbon & 5.48 & $9,753,523$ & $8,599,198$ & 8,52246 & 155,809 & $791,822,698$ & $49,79,343$ & $20,778,16$ & 1,499 & 214 \\
\hline & 3Pencegahah Banjir & 53.26 & $94,794,278$ & $83,575,42$ & $82,82,952$ & $5,939,97,537$ & $7,055,07,5,59$ & $481,80,545$ & $201,95,42$ & $14,574,692,136$ & $2,082,098,877$ \\
\hline & 4 Transpotasi Air & 5.8 & $10,323,072$ & $9,101,341$ & $9,020,160$ & $646,208,703$ & $838,060,519$ & $52,74,487$ & $21,99,860$ & $1,587,180,142$ & $266,740,220$ \\
\hline & 5 Keankekragamann $\mathrm{H}$ & 10.35 & $18,42,344$ & & & $1,153,148,289$ & $1,45,504,548$ & $93,39,817$ & $39,24,095$ & & \\
\hline & Non Extractive & 134.4 & $239,210,496$ & $210,900,050$ & $209,018,880$ & $14,974,215,460$ & $19,11,885,139$ & $1,215,960,520$ & $509,604,480$ & $36,778,795,025$ & $5,54,113,575$ \\
\hline & Nilai IonPenggumaan & 1793 & $31,912,531$ & $28,135,999$ & $27,884,736$ & $1,997,676,214$ & $2,500,762,950$ & $162,418,433$ & 67,$98 ; 181$ & $4,906,575,854$ & $700,939,408$ \\
\hline & 1 Niliai Pithan & 7.58 & $13,491,187$ & $11,89,5,512$ & $11,788,416$ & $84,527,925$ & $1,05,558,403$ & $68,78,726$ & 28,74, 086 & $2,074,280,255$ & $296,325,751$ \\
\hline & 2 Nilia Eksiste & 10.35 & $18,42,344$ & $16,241,187$ & & $1,153,148,899$ & $1,495,504,548$ & $93,39,817$ & $39,24,095$ & 2,832,295;,999 & $404,613,657$ \\
\hline & Biajag Total Ekonomi & & $479,631,283$ & $422,867,154$ & $419,095,296$ & $30,024,193,319$ & $38,938,025,650$ & $2,438,073,222$ & $1,021,787,316$ & $73,73,673,440$ & $10,334,810,463$ \\
\hline
\end{tabular}

Berbeda dengan tahun 2011, pada tahun 2012 nilai kerugian ekonomi akibat deforestasi mengalami peningkatan yang sangat drastic sekali menjadi sebesar Rp 30.024.193.319,-Peningkatan nilai kerugian ekonomi akibat deforestasi ini, dipicu oleh meningkatnya angka deforestasi dan meningkatnya kurs mata uang dollar Amerika. Trend kenaikan kerugian ekonomi akibat deforestasi terus terjadi pada tahun 2013. Sekalipun kenaikan nilai kerugian ekonomi akibat deforestasi tahun 2013 dipicu oleh kenaikan nilai kurs Dollar Amerika terhadap Rupiah, namun kenaikan nilai kurs Dollar Amerika terhadap Rupiah pada tahun 2013 sangat signifikan yang mendorong kenaikan nilai kerugian ekonomi akibat deforestasi yang terjadi pada kawasan hutan konservasi tahun 2013 mencapai angka sebesar Rp 38.938.025.650,-. Pada tahun 2014, nilai kerugian ekonomi akibat deforestasi kembali mengalami penurunan disebabkan menurunnya angka luasan deforestasi sehingga nilai kerugian ekonomi akibat deforestasi hanya sebesar Rp 2.438.073.222,-. Fenomena yang sama juga terjadi pada nilai kerugian ekonomi akibat deforestasi pada tahun 2015. Meskipun terjadi kenaikan kurs Dollar Amerika, namun karena luasan angka luasan deforestasi turun, maka nilai kerugian ekonomi akibat deforestasi yang terjadi pada kawasan hutan tahun 2015 menjadi sebesar Rp 1.021.787.316,-. Berikut ini tabel yang menyajikan data perkiraan nilai kerugian ekonomi akibat deforestasi pada kawasan hutan konservasi di Kalimantan Barat tahun 2009-2015. 


\subsubsection{Perbandingan Nilai Kerugian Ekonomi Akibat Deforestasi Menurut Status Kawasan Hutan di Kalimantan Barat.}

Selama 7 (tujuh) tahun, angka nilai kerugian ekonomi akibat deforestasi yang tejadi pada semua kawasan hutan di Kalimantan Barat mengalami flukatuasi yang cenderung menurun. Sementara itu secara keseluruhan total nilai kerugian ekonomi akibat deforestasi selama periode 2009 sampai dengan 2015 adalah sebesar Rp 1.699.047.455.930,-, dalam hal ini nilai kerugian ekonomi akibat deforestasi yang paling tinggi adalah terjadi pada hutan produksi sekunder dengan total nilai kerugian sebesar Rp 1.071.061.461.085,- atau memberikan kontribusi sebesar 63,26 persen dari total keseluruhan nilai kerugian ekonomi akibat deforestasi di Kalimantan Barat. Diduga kecenderungan tingginya nilai kerugian ekonomi akibat deforestasi yang terjadi pada kawasan hutan produksi sekunder, karena pada kawasan ini lebih mudah untuk melakukan alih fungsi lahan untuk dijadikan sebagai lahan perkebunan kelapa sawit. Setelah hutan produksi sekunder, maka nilai kerugian ekonomi akibat deforestasi yang cukup besar terjadi padan hutan produksi primer dengan nilai kerugian ekonominya adalah sebesar $\operatorname{Rp} 410.476 .500 .943$,- atau memberikan kontribusi sebesar 24,24 persen dari total nilai kerugian ekonomi akibat deforestasi selama periode tahun 2009 sampai dengan tahun 2015.

Tabel 6. Perbandingan Perkiraan Nilai Ekonomi Deforestasi pada Status Kawasan Hutan di Kalimantan Barat Tahun 2009-2015 (Dalam Rupiah)

\begin{tabular}{|c|c|c|c|c|c|c|c|c|c|}
\hline \multirow[t]{2}{*}{ No. Status Hutan } & \multicolumn{7}{|c|}{ Tahun } & & \multirow{2}{*}{ Proventase } \\
\hline & 2009 & 2010 & 2011 & 2012 & 2013 & 2014 & 2015 & & \\
\hline 1 Hutan Produksi Primer & $15,989,739,466$ & $14,099,196,513$ & $13,884,238,368$ & $150,106,472,858$ & $194,671,331,488$ & $11,894,710,115$ & $10,202,811,344$ & $410,760,500,943$ & 24.24 \\
\hline 2 Hutan Prodklks Skhunder & $70,627,138,821$ & $62,668,451,226$ & $61,713,033,921$ & $312,848,002,169$ & $405,728,920,119$ & $57,500,013,997$ & $100,355,900,331$ & $1,071,061,461,085$ & 63.26 \\
\hline 3 Hutan Lindung & $1,200,743,944$ & $1,058,636,173$ & $1,049,193,432$ & $53,394,860,117$ & $69,247,170,463$ & $8,099,084,688$ & $3,306,132,196$ & $137,765,820,663$ & 8.14 \\
\hline 4 Hutan Konserrasi & $479,631,283$ & $42,866,154$ & $419,095,296$ & $30,024,193,319$ & $38,938,025,650$ & $2,438,073,222$ & $1,021,787,316$ & $73,743,673,440$ & 4.36 \\
\hline Total Biaya Ekonomi & $88,197,253,164$ & 'm7,759,151,066 & $77,065,561,017$ & $546,373,528,464$ & $708,585,477,720$ & $80,361,882,52,22$ & $114,704,631,977$ & $1,093,047,455,930$ & 10 \\
\hline
\end{tabular}

Terkait dengan hutan lindung menurut hasil perhitungan deforestasi yang terjadi di kawasan hutan ini telah menghasilkan nilai kerugian ekonomi sebesar Rp 137.765.820.663,- atau memberikan kontribusi terbesar ketiga setelah hutan produksi sekunder dan hutan produksi primer, dengan kontribusi sebesar 8,14 persen dari total nilai kerugian ekonomi akibat deforestasi di Kalimantan Barat selama periode tahun 2009 sampai dengan tahun 2015. Hal yang sama juga terjadi pada kawasan hutan konservasi, akibat terjadi deforestasi pada kawasan hutan ini, nilai kerugian ekonomi yang ditimbulkannya selama periode tahun 2009 sampai dengan tahun 2015 mencapai angka sebesar Rp 74.743.673.240,- atau memberikan kontribusi 4,36 persen total nilai kerugian ekonomi di Kalimantan Barat, dan ini merupakan angka nilai kerugian ekonomi akibat deforestasi yang terkecil dibandingkan dengan kawasan hutan lainnya. Berikut tabel 6 yang menyajikan perbandingan nilai kerugian ekonomi akibat deforestasi pada kawasan hutan di Kalimantan Barat selama periode tahun 2009 - 2015. 


\subsection{Pengaruh biaya ekonomi Akibat deforestasi terhadap PDRB subsektor Kehutanan}

Sebagaimana selama ini dilakukan, perhitungan terhadap Produk Domestik Brutto atau Produk Domestik Regional Brutto yang seringkali digunakan sebagai salah satu indicator untuk melihat kemajuan ekonomi suatu negara atau daerah, tidak memasukkan dampak yang ditimbulkan terutama dampak dari kerugian ekonomi karena kerusakan lingkungan sebagai akibat dari eksploitasi atau pemanfaatan sumberdaya alam untuk pembangunan itu sendiri. PDB atau PDRB yang tidak memasukkan dampak lingkungan dalam perhitungannya seringkali disebut dengan PDB atau PDRB coklat.

Kekhawatiran makin menipisnya cadangan sumberdaya alam akibat dari eksploitasi yang berlebihan sehingga menyebabkan terjadinya penurunan kualitas serta kerusakan lingkungan, mendorong para ahli ekonomi yang peduli terhadap lingkungan menawarkan konsep pembangunan berkelanjutan dan berwawasan lingkungan. Salah satu implementasi konsep ini adalah penyempurnaan atau perbaikan dalam menghitung Produk Domestik Brutto atau Produk Domestik Regional Brutto dengan hanya memasukkan dampak berkurangnya cadangan sunberdaya alam saja disebut dengan PDB atau PDRB semi hijau. Selanjutnya PDB atau PDRB yang dalam perhitungannya memasukkan komponen nilai deplesi dan degradasi sumberdaya alam disebut dengan PDB atau PDRB hijau. Namun bila ditelaah lebih jauh, konsep PDB atau PDRB hijau tidak hanya sebatas sektor kehutanan saja tetapi juga sektor pertambangan terutama tambang mineral yang juga memberikan dampak pada lingkungan baik yang berkaitan dengan akibat deplesi dan degradasi.

Berkenaan terjadinya deforestasi, tentu saja berkaitan dengan dengan sektor kehutanan yang merupakan bagian dari sektor pertanian, kehutanan dan perikanan dalam PDB atau PDRB. Seringkali nilai sub sektor kehutanan yang tercantum di dalam PDB atau PDRB adalah nilai yang tidak memasukkan nilai deplesi dan degredasi. Sehingga apabila kedua nilai tersebut dimasukkan, maka sudah pasti akan mengurangi nilai subsektor kehutanan. Terkait dengan hal tersebut, hasil perhitungan mendapatkan bahwa pada tahun 2009 nilai PDRB Coklat subsektor kehutanan Kalimantan Barat adalah sebesar Rp 1.532.367.980.000,00, namun dengan memasukkan nilai deplesi dan degradasi kedalam PDRB, menghasikan nilai PDRB hijau subsektor kehutanan menjadi Rp 1.444.160.726.836,10.-. berkurangnya nilai PDRB coklat subsektor kehutanan yang lebih kecil dibandingkan dengan nilai PDRB hijau, dikarenakan nilai deplesi dan degradasi pada tahun 2009 yang sebesar Rp 88.197.253.163,90 menjadi pengurang dari PDRB coklat. Bila dilihat dari kontribusinya, nilai deplesi dan nilai degradasi memberikan 5,76 persen nilai PDRB coklat subsektor kehutanan tahun 2009.

Dibandingkan dengan tahun 2009, kontribusi nilai deplesi dan degradasi terhadap nilai PDRB Coklat subsektor kehutanan adalah lebih rendah yang hanya mencapai angka sebesar 4,91 persen. Turunnya kontribusi nilai deplesi dan degradasi ini menjadikan PDRB hijau subsektor kehutanan tahun 2010 meningkat menjadi Rp 1,504.534.288.933,85,-. Fenomena yang sama terjadi juga dengan kontribusi nilai deplesi dan degradasi tahun 2011, yang lebih rendah dibandingkan dengan tahun 2010. Kontribusi nilai deplesi dan degradasi terhadap PDRB coklat subsektor kehutanan tahun 2011 turun menjadi 3,83 persen, sehingga menyebabkan nilai PDRB hijau subsektor kehutahan pada tahun 2011 naik menjadi Rp 1.934.743.538.983,00,-.

Namun yang cukup menarik untuk amati, adalah terjadinya penurunan nilai PDRB hijau subsektor kehutanan pada tahun 2012 yang lebih kecil dibandingkan dengan tahun 2011, 
sekalipun nilai PDRB coklat subsektor kehutanan pada tahun 2012 lebih besar dibandingkan tahun 2011. Rendahnya nilai PDRB hijau subsektor kehutanan tahun 2012 ini, dikarenakan terjadi kenaikan kontribusi nilai deplesi dan degradasi yang mencapai angka 25,73 persen terhadap nilai PDRB coklat, sehingga menyebabkan nilai PDRB hijau subsektor kehutanan pada tahun 2012 turun menjadi Rp 1.577.354.371.536,34,-. Penurunan nilai PDRB hijau subsektor kehutanan terus berlanjut pada tahun 2013, dengan nilai PDRB hijau subsektor kehutanan yang lebih rendah dibandingkan dengan nilai tahun 2012, sekalipun nilai PDRB coklat sektor ini lebih besar dibandingkan dengan tahun 2012. Sama seperti yang terjadi pada tahun 2012, menurunnya nilai PDRB hijau subsektor kehutanan pada tahun 2013, karena kontribusi yang meningkat dari nilai deplesi dan degradasi yang lebih besar dibandingkan tahun 2012. Kontribusi nilai deplesi dan degradasi terhadap PDRB coklat subsektor kehutanan pada tahun 2013 mencapai angka 32,38 persen, sehingga menyebabkan PDRB hijau subsektor kehutanan pada tahun 2013 turun menjadi sebesar Rp 1.479.639.252.280,18,-.

Tabel 7. Produk Domestik Regional Hijau Subsektor Kehutanan Kalimantan Barat Atas Dasar Harga yang Berlaku Tahun 2009-2015 (Dalam Jutaan Rupiah)

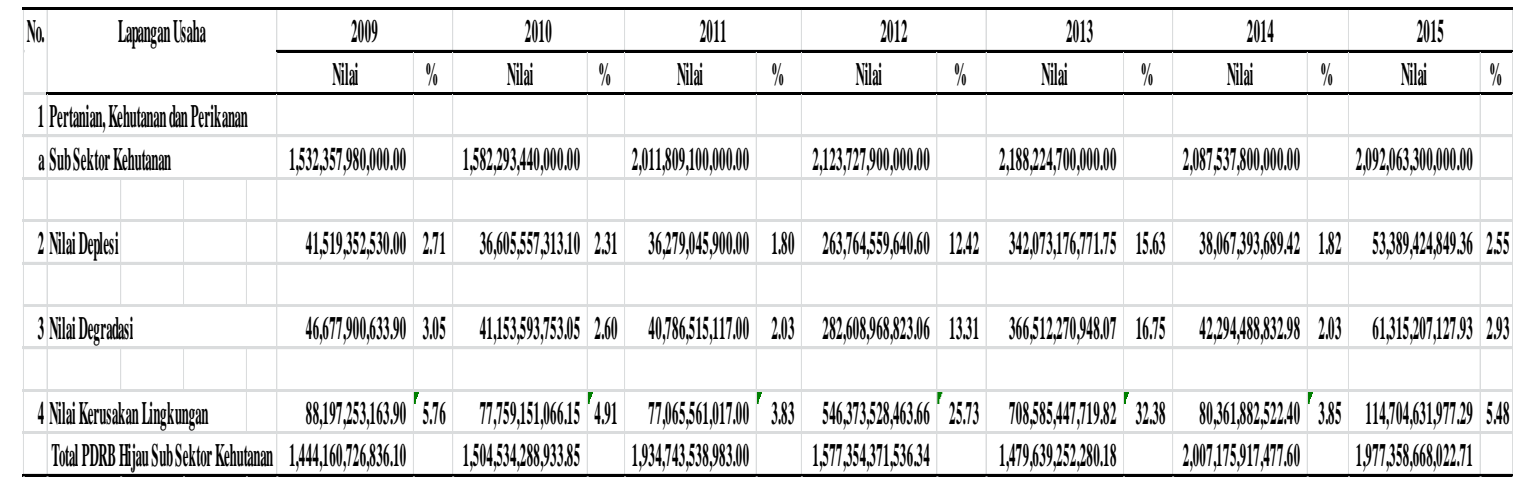

Setelah mengalami penurunan selama 2 (dua) tahun berturut-turut yaitu tahun 2012 dan 2013, pada tahun 2014, nilai PDRB hijau subsektor kehutanan mengalami kenaikan. Kenaikan ini, disebabkan menurunnya kontribusi nilai deplesi dan degradasi terhadap nilai PDRB coklat subsektor kehutanan yang semula dari 32,38 persen pada tahun 2013 turun menjadi 3,85 persen pada tahun 2014. Penurunan kontribusi nilai deplesi dan degradasi terhadap nilai PDRB coklat subsektor kehutanan yang sangat signifikan, menjadikan nilai PDRB hijau subsektor kehutanan pada tahun 2014 meningkat menjadi Rp 2.007.175.917.477,60,-. Kenaikan PDRB hijau subsektor kehutanan pada tahun 2014 tidak terjadi pada tahun 2015. Justru sebaliknya, pada tahun 2015 nilai PDRB hijau subsektor kehutanan mengalami penurunan sehingga menjadi sebesar Rp 1.977.358.668.022,71,-. Penurunan ini disebabkan oleh meningkatnya kontribusi nilai deplesi dan degradasi yang semula pada tahun 2014 sebesar 3,85, pada tahun 2015 kontribusi ini turun menjadi 5,48 persen. Berikut data yang menyajikan perhitungan Produk Domestik Regional Hijau Kalimantan Barat Subsektor Kehutanan Atas Dasar Harga Berlaku Tahun 2009 2015 yang disajikan pada Tabel 7.

\section{SIMPULAN}

Total nilai kerugian ekonomi akibat deforestasi pada kawasan hutan di Kalimantan Barat selama periode 2009 sampai dengan 2015 adalah sebesar Rp 1.699.047.455.930,-. Diantara 
beberapa kawasan hutan, nilai kerugian ekonomi akibat deforestasi yang paling tinggi adalah terjadi pada hutan produksi sekunder dengan total nilai kerugian sebesar Rp 1.071.061.461.085,atau memberikan kontribusi sebesar 63,26 persen dari total keseluruhan nilai kerugian ekonomi akibat deforestasi. Sedangkan kerugian ekonomi akibat deforestasi yang terkecil terjadi pada kawasan hutan konservasi dengan nilai angka sebesar Rp 73.743.673.240,- atau memberikan kontribusi 4,36 persen dari total nilai kerugian ekonomi akibat deforestasi selama periode tahun 2009 sampai dengan tahun 2015.

Nilai deplesi dan degradasi akibat terjadinya deforestasi pada kawasan hutan selama periode 2009-2015 di Kalimantan Barat, telah memberikan kontribusi berkurangnya nilai PDRB coklat subsektor kehutanan, sehingga menghasilkan nilai PDRB Hijau subsektor kehutanan. Hasil perhitungan mendapatkan bahwa nilai kerugian ekonomi akibat deforestasi (yang merupakan penjumlahan nilai deplesi dan degradasi) tertinggi selama periode tahun 2009 sampai dengan tahun 2015 terjadi pada tahun 2013 dengan nilai kerugian ekonomi sebesar Rp 708.585.447.719,82. Hal ini telah memberikan pengurangan pada nilai PDRB coklat subsektor kehutanan tahun 2013 yang semula sebesar Rp 2.188.224.700.000, menjadi sebesar Rp. 1.479.639.252.280,18, dan angka ini merupakan nilai PDRB hijau subsektor kehutanan tahun 2013. Bila dilihat secara prosentase, pengurangan nilai PDRB coklat subsektor kehutanan tahun 2013 yang menghasilkan nilai PDRB hijau adalah sebesar 32,38 persen yang merupakan kontribusi dari nilai kerugian ekonomi akibat deforestasi terhadap nilai PDRB coklat subsektor kehutanan tahun 2013. Sementara itu nilai kerugian ekonomi akibat deforestasi terkecil terjadi pada tahun 2011 dengan nilai kerugian ekonomi sebesar Rp. 77.065.561.017,00. Angka ini telah memberikan pengurangan pada nilai PDRB coklat subsektor kehutanan tahun 2011 yang semula sebesar Rp 2.011.809.100.000,- menjadi sebesar Rp. 1.479.639.252.280,18 dan angka ini merupakan nilai PDRB hijau subsektor kehutanan tahun 2011. Kontribusi nilai kerugian ekonomi akibat deforestasi terhadap pengurangan nilai PDRB coklat subsektor kehutanan tahun 2011 menjadi PDRB hijau subsektor kehutanan adalah sebesar 3,83 persen.

\section{DAFTAR PUSTAKA}

Adriana, M. (2004). Mempertanyakan Komitmen Parpol Terhadap Isu Lingkungan. Retrieved from www.conservation.or.id/site/modules/detail.daily.php?textid

Alam, S., Supratman, \& KS, M. A. (2009). Ekonomi Sumber Daya Hutan. Makassar: Laboratorium Kebijakan dan Kewirausahaan Kehutanan Fakultas Kehutanan Universitas Hasanuddin.

Andersen, L. E. (1997). A Cost-Benefit Analysis Of Deforestation In The Brazillian Amazon. Rio de Janeiro.

Arrow, K., Bolin, B., Costanza, R., Dasgupta, P., Folke, C., Holling, C. S., ... Pimentel, D. (1995). Economic Growth, Carrying Capacity, and the Environment Science. Science, 268, $520-521$.

Barbier, E. B., Burgess, J. C., \& Folke, C. (1994). Paradise Lost? - The Ecological Economics of Biodiversity. London: Earthscan Publications.

Beckermen, W. (1992). Economic Growth and the Environment: Whose Growth! Whose Environment? World Development, 20, 481-496. 
Bhagwati, J. (1993). The Case For Free Trade. The Scientific American, 42-49.

Daly, H. E. (1977). Steady-state Economics: The Economics of Biophysical Equilibrium and Mor-al Growth. San Francisco: W. H. Freeman.

Damnyag, L., Tayynela, T., Appiah, M., Saastamoinen, O., \& Pappinen, A. (2011). A Case of Two Forest Districts in Ghana. Ecological Journal, 70, 2503-2510.

Ekins, P. (1997). The Kuznets Curve For The Environment And Economic Growth: Examining The Evidence. Environment And Planning, 29, 805-830.

FAO. (2001). State Of The World's Forests. Rome.

Fauzi, A. (2004). Ekonomi Sumberdaya Alam dan Lingkungan: Aplikasi Dan Teori. Jakarta: PT Gramedia Pustaka Utama.

Forest Watch Indonesia. (2011). Potret Keadaan Hutan Indonesia Periode 2000-2009. Bogor.

Forest Watch Indonesia dan Global Forest Watch. (2011). Keadaan Hutan Indonesia. Bogor.

Georgescu-Roegen. (1977). The Entropy Law and the Economic Process. Cambridge, MA: Harvard University Press.

Hernowo, B. (2011). Green Economics, Tren Emisi Gas Rumah Kaca, Dan Perubahan Iklim di Indonesia (No. Materi Diklat Non Gelar "Green Economic"). Bandung.

Kusnawaty, K. (2013). Evaluasi Ekonomi Sumber Daya Alam Dan Lingkungan Sektor Pertambangan Dalam Penyusunan Produk Domestik Regional Bruto (PDRB) Hijau Di Kabupaten Ketapang. Pontianak: (Tesis), Universitas Tanjungpura, Indonesia.

Meier, \& Y, S. (2001). Frontiers Of Development Economics. Madison Avanue New York. N. Y. 10016: Oxford University Press, Inc 198.

Muaningshe, M. (1993). Environmental Economics and Sustainable Development (No. World Bank Environment Paper Number 3). Washington D.C.

Nurfatriani, F. (2006). Konsep Nilai Ekonomi Total Dan Metode Penilaian Sumberdaya Hutan. Jurnal Ekonomi, 3(1).

Panayotou, T. (1993). Empirical Tests And Policy Analysis Of Environmental Degradation At Different Stages Of Economic Development. Geneva: International Labor Office, Technology And Employment Programme.

Pearce, D. W., \& Turner, K. (1990). Economics of Natural Resources and The Environment. New York: Harvester Wheatsheaf.

REDD+ KALBAR. (2013). Strategi dan Rencana Aksi Provinsi (SRAP) REDD+ Kalimantan Barat.

Stagl, S. (1999). Delinking Economic Growth From Environmental Degradation? A Literature Survey On The Environmental Kuznets Curve Hypothesis. Wiena.

Stern, D. I., Common, M. S., \& Barbier, E. B. (1996). Economic Growth And Environmental Degradation: The Environmental Kuznets Curve And Sustainable Development. World Development, 24, 1151-1160.

Suparmoko, M. (2006). PDRB Hijau (Konsep Dan Metodologi). Jakarta.

Suparmoko, M., \& Ratnaningsih, M. (2011). Ekonomika Lingkungan. Yogyakarta: BPFE UGM.

Sutcliffe, J. P. (2009). The Extent And Economic Costs Of Deforestation In South-West Ethiopia: A Preliminary Analysis. Ethiopia. 
Torras, M. (2000). The Total Economic Value Of Amazonian Deforestation. Ecological Economics Journal, 33, 283-297.

United Nations Statistical Office (UNSO). (2000). System Of Integrated Economic And Environmental Account.

Yani, A. (2015). Penilaian Kawasan Hutan Dalam Penentuan Kelayakan Luas Areal Perkebunan Kelapa Sawit (Suatu Pendekatan Konseptual). Jurnal Ekonomi Bisnis Dan Kewirausahaan, $\begin{array}{lcr}\text { 4(3), } & 336-354 . & \text { Retrieved } \\ \text { http://jurnal.untan.ac.id/index.ph/JJ/article/view/15328/13520 }\end{array}$

from 